\title{
IŠVENGIAMOS HOSPITALIZACIJOS KAIP AMBULATORINĖS SVEIKATOS PRIEŽIÜROS VEIKLOS ATSPINDYS LIETUVOJE 2012 M.: KĄ GALIMA PAKEISTI?
}

\author{
Sandra Mekšriūnaitè \\ Higienos instituto Sveikatos informacijos centras \\ Didžioji g. 22, LT-01128, Vilnius, Lietuva \\ Telefonas (+370 5) 2773302 \\ Elektroninis paštas Sandra.Meksriunaite@hi.lt

\section{Romualdas Gurevičius} \\ Higienos instituto Sveikatos informacijos centras \\ Didžioji g. 22, LT-01128, Vilnius, Lietuva \\ Telefonas (+370 5) 2622781 \\ Elektroninis paštas Romualdas.Gurevicius@hi.lt \\ Pateikta $2015 \mathrm{~m}$. vasario 23 d., parengta spausdinti $2015 \mathrm{~m}$. balandžio $24 \mathrm{~d}$.
}

DOI:10.13165/SPV-15-1-8-03

\section{Ivadas}

Išvengiamos hospitalizacijos ( $\mathrm{IH}$, angl. avoidable hospitalizations, preventable hospitalizations) yra tokios hospitalizacijos, kurių visiškai arba didelès dalies galima išvengti, jeigu būtų pakankamai prieinama ir kokybiška ambulatorinė sveikatos priežiūra, kurioje vykdoma ligų profilaktika, ankstyva diagnostika ir suteikiamas tinkamas gydymas. Ligos, dèl kurių hospitalizacijos laikomos išvengiamomis, vadinamos ambulatoriškai valdomomis ligomis (AVL, angl. ambulatory care sensitive conditions) $)^{1,2}$.

Health Outcomes Section, Development and Resources Branch, Public Health Division. The Victorian Ambulatory Care Sensitive Conditions Study: Preliminary Analyses [interaktyvus]. Public Health Division, Victorian Government Department of Human Services, Melbourne, Victoria, 2001 [žiūrèta 2015-02-10]. <http://docs.health.vic.gov.au/docs/doc/D98EB1945C0A612ECA257 87300137A6F/\$FILE/prelimanalyses.pdf>.

2 Jackson, G.; Tobias, M. Potentially avoidable hospitalisations in New Zealand, 1989-98. Australian and New Zealand Journal of Public Health. 2001, 25(3): 212-221. 
IH problema buvo iškelta supratus, kad nevisiškai išnaudojamos ambulatorinès sveikatos priežiūros galimybės teikiant asmens sveikatos priežiūros paslaugas. Kokybiškai ir laiku teikiamos šios paslaugos padeda užkirsti kelią atsirasti kai kurioms ligoms, valdyti lètinių ligų eigą ir sustabdyti sveikatos blogèjimą kartu sudaromos pakankamos sąlygos pacientams išlaikyti tokią sveikatos būklę, kuri nereikalautų stacionarinès priežiūros ${ }^{3,4}$.

Tai ypač aktualu šalyse, kurios gyventojams teikiamas sveikatos priežiūros paslaugas finansuoja iš bendro biudžeto (Australija, Didžioji Britanija, Kanada, JAV, Ispanija). Stacionarinè sveikatos priežiūra yra pati brangiausia ir šių paslaugų teikimas žymiai padidina sveikatos priežiūros biudžeto išlaidas. Pavyzdžiui, JAV $2006 \mathrm{~m}$. buvo daugiau nei $4 \mathrm{mln}$. IH, kurioms išleista beveik $31 \mathrm{mlrd}$. dolerių ir šios išlaidos sudare 10 proc. viso sveikatos priežiūros biudžeto (angl. patient care). Penktadalis visų valstybiniu draudimu (Medicare) apdraustų pacientų hospitalizacijų buvo išvengiamos, o išlaidos šių pacientų hospitalizacijoms sudarè apie du trečdalius visoms IH išleistų $31 \mathrm{mlrd}$. dolerių. Stazinis širdies nepakankamumas ir bakterine pneumonija buvo dvi pagrindinès AVL, kurios pareikalavo pusės IH išlaidų (atitinkamai 8,4 mlrd. ir 7,2 mlrd. dolerių). IH dèl lètinès obstrukcinès plaučių ligos ir astmos kainavo apie 4,9 mlrd. dolerių, o tai sudare 16 proc. visų IH išlaidų ${ }^{5}$. Taip pat nustatyta, kad JAV astma užèmé trečiąją vietą IH struktūroje ir dèl astmos buvo prarasta daugiau nei $3 \mathrm{mln}$. darbo dienų, todèl atsirado papildomų išlaidų valstybei ${ }^{6}$. Lietuvoje, Valstybinès ligonių kasos duomenimis, $2013 \mathrm{~m}$. vien tik vaistams, skirtiems hipertenzijai, antro tipo cukriniam diabetui ir astmai gydyti, buvo išleista $235 \mathrm{mln}$. Lt PSDF biudžeto lèšų (šioms ligoms gydyti vaistais 2012 ir 2013 m. buvo išleista daugiausiai PSDF biudžeto lëšų, skirtų ligoms gydyti vaistais) ${ }^{7}$.

IH koncepcijos pradžia laikomi 1970 m., kai keliose publikacijose buvo siūloma tam tikras sveikatos būkles laikyti indikatoriais, rodančiais galimas ambulatorinès sveikatos priežiūros, suteiktos prieš paciento hospitalizaciją, problemas. Nuo tada buvo paskelbti kelių dešimčių tyrimų rezultatai, apžvalgos, skirtingose šalyse nagrinėjančios AVL sąrašą, IH problemą ir jai įtaką darančius veiksnius ${ }^{8}$.

Health Outcomes Section, Development and Resources Branch, Public Health Division, op. cit.

Maslow, K.; Ouslander, J. G. Measurement of Potentially Preventable Hospitalizations [interaktyvus]. Long-term Quality Alliance, 2012 [žiūrèta 2015-02-10]. <http://www.ltqa.org/wp-content/ themes/ltqaMain/custom/images//PreventableHospitalizations_021512_2.pdf>.

5 Jiang, H. J.; Russo, C. A.; Barrett, M. L. HCUP Statistical Brief \#72. Nationwide Frequency and Costs of Potentially Preventable Hospitalizations, 2006 [interaktyvus]. U.S. Agency for Healthcare Research and Quality, Rockville, 2009 [žiūrèta 2015-02-10]. <http://www.hcup-us.ahrq.gov/reports/ statbriefs/sb72.jsp >.

6 Kowalski, A. F. Reducing asthma morbidity and mortality. Cost containment strategies. American Association of Occupational Health Nurses. 2000, 48(9): 418-422.

7 Valstybinè ligonių kasa. Ligoniu kasos: 2013-ujų apžvalga. Vilnius, 2014.

8 Maslow, K.; Ouslander, J. G., supra note 4, p. 12-13. 
Šiuo metu IH rodiklius rutiniškai stebi tokios šalys kaip Australija ${ }^{9}, \mathrm{JAV}^{10}$, Kanada $^{11}$, Didžioji Britanija ${ }^{12}$. Jose vykdoma stebėsena siekiama gauti netiesioginés informacijos apie ambulatorinès sveikatos priežiūros veiklą (prieinamumą, efektyvumą, prevencinès veiklos kokybę).

Visos šalys naudoja patvirtintą AVL sąrašą atsižvelgdamos į savo šalies sveikatos politiką, medicinos praktiką, gyventojų sveikatos problemas. I šj sąrašą dažnai yra ịtrauktos tokios AVL kaip cukrinis diabetas (ir jo komplikacijos), stazinis širdies nepakankamumas, kai kurios skiepais išvengiamos ligos (gripas, pneumonija), stazinis širdies nepakankamumas, krūtinès angina, kai kurios ūmios ligos (pavyzdžiui, pielonefritas arba kitos šlapimo takų infekcijos, dehidratacija $)^{13}$. Skaičiuojami IH rodikliai populiacijoje, IH struktūra pagal skirtingas AVL, rodikliai lyginami tarp skirtingų teritorinių vienetų.

Daugiau IH aspektų nei rutininëje stebėsenoje nagrinëjama atskiruose moksliniuose tyrimuose, kuriuose galima apžvelgti ne tik populiacijos rodiklius, bet ir asmens lygio veiksnius. Dabar žinoma, kad IH skaičiui ịtaką daro labai daug veiksnių: ligų paplitimas bendroje populiacijoje, demografinè šalies charakteristika, diagnostikos galimybès, pacientų polinkis kreiptis ị gydytoją sunegalavus, sveikatos priežiūros ištekliai, gydytojų kvalifikacija, ịvairūs socioekonominiai veiksniai (galimybė nuvykti ị gydymo įstaigą, galimybe atsiprašyti iš darbo, socialine apsauga nedarbingumo atveju) ir kt. . $^{14,15,16}$

Apskritai visus IH ịtaką darančius veiksnius galima suskirstyti $\mathfrak{i}$ tris grupes: asmeninès savybės (person priorities), programinè veikla (programme priorities), teritoriniai ypatumai (place priorities). Asmeninès savybès apima paciento sveikatos istoriją, esamos būklès sunkumą, gretutines ligas, žalingus ịpročius, fizines savybes (kūno masès indeksą, arterinị kraujo spaudimą), amžių, lytị, šeiminę padètị, socialinius ryšius. Programinè veikla yra susijusi su paciento sugebejjimu

$9 \quad$ Katterl, R., et al. Potentially avoidable hospitalisations in Australia: Causes for hospitalisations and primary care interventions. PHCRIS Policy Issue Review. Adelaide: Primary Health Care Research \& Information Service, 2012.

10 Agency for Healthcare Research and Quality. Prevention Quality Indicators Overview. U.S. Department of Health and Human Services [interaktyvus]. 2015 [žiürèta 2015-02-10]. <http://www. qualityindicators.ahrq.gov/modules/pqi_overview.aspx>.

11 Statistics Canada. Health system performance, effectiveness [interaktyvus].Ottawa, 2015 [žiūrèta 2015-02-10]. <http://www.statcan.gc.ca/pub/82-221-x/2013001/def/def3-eng.htm\#effec3ac>.

12 Nutffield Trust \& the Health Foundation. Indicator: Potentially preventable emergency hospital admissions. QualityWatch [interaktyvus]. 2015 [žiūrèta 2015-02-10]. <http://www.qualitywatch. org.uk/indicator/potentially-preventable-emergency-hospital-admissions $>$.

13 Maslow, K.; Ouslander, J. G., supra note 4, p. 14-17.

14 Billings, J.; Anderson, G. M.; Newman, L. S. Recent Findings on Preventable Hospitalizations. Health Affairs. 1996, 15(3): 239-249.

15 Bindman, A. B., et al. Preventable Hospitalizations and Access to Health Care. The Journal of the American Medical Association. 1995, 274(4): 305-311.

16 Magan, P., et al. Geographic variations in avoidable hospitalizations in the elderly, in a health system with universal coverage. BMC Health Services Research. 2008, 8(42): 48-52. 
valdyti savo ligą, sveikatos priežiūros paslaugų teikimu (prieinamumu, koordinavimu, gydymo praktika, ištekliais). Teritoriniai ypatumai daro įtaką IH per vietinio lygio veiksnius: atmosferos (oro užterštumas, klimato ypatumai, saulès aktyvumas), landšafto ypatumus, administracinius išteklius, bendrą socialinị bendruomenès lygị (nedarbas, socialinė parama), sveikatos priežiūros paslaugu prieinamumas laiko ir išteklių atžvilgiu ${ }^{17}$.

Veiksniai, kurių negalima pakeisti sisteminėmis priemonėmis (amžius, lytis, gyvenamoji vietove, išsilavinimas ir pan.), gali padèti numatyti tikslines (rizikos) asmenų grupes. Kai kuriuos kitus veiksnius galima valdyti valstybinemis ar vietinio lygio priemonemis. Tokia IH koncepcijos prigimtis lemia tai, kad tikslingai nukreipti sveikatos politikos ir sveikatos priežiūros vadybos sprendimai gali sumažinti IH skaičių. Dèl šios priežasties šalyse, kurioms IH problema yra aktuali, turètų būti stebimi IH rodiklių pokyčiai ir skirtumai valstybès mastu bei skirtingose teritorijose, tarp skirtingų gyventojų grupių, aiškinamasi IH priežastys ir rengiamos rekomendacijos bei imtasi pokyčių, galinčių sumažinti IH skaičių.

Kadangi IH tikslas yra ịvertinti ambulatorinès sveikatos priežiūros paslaugų kokybę ir prieinamumą, teoriškai laikoma, kad ši problema gali būti sprendžiama trimis pagrindinemis veiksmų kryptimis:

- mažinant sergamumą ligomis, kurios yra išvengiamos aktyviai teikiant ambulatorines paslaugas (vakcinacija);

- laiku suteikiant tinkamą pagalbą pacientams, susirgusiems ūmia liga, kad jų būklè nepasunkètų tiek, jog būtų būtina hospitalizacija;

- tinkamai valdant lètines ligas, koreguojant ambulatorinị gydymą, keičiant gyvensenos ípročius, kad lètinè liga nesikomplikuotų ${ }^{18}$.

Taip pat galima pasinaudoti kitų šalių gerąja patirtimi. Pavyzdžiui, JAV siekiant padèti karo veteranams, sergantiems cukriniu diabetu, geriau valdyti savo ligą atliktas tyrimas, kurio metu jo dalyviai dvejus metus kasdien atsakinèdavo telefonu ị klausimus apie savo sveikatos būklę ir sveikatos priežiūrą. Atsakymus kiekvieną dieną ịvertindavo slaugytojos ir, jeigu reikia, rekomenduodavo jiems kreiptis ị savo šeimos gydytoją dẻl konsultacijos. Ši programa buvo veiksminga ir sumažino tikimybę būti hospitalizuotam ne tik dèl cukrinio diabeto ar jo komplikacijų, bet ir dèl kitų ligų. Nemažai gerosios praktikos pavyzdžių pateikiama mažinant ir kitų AVL hospitalizacijų skaičių ir paprastai IH skaičiaus pokyčiai yra susiję su dažnesniu pacientų ir ambulatorinę pagalbą teikiančių gydytojų ar slaugytojų kontaktu, dažnesne lètinių ligų valdymo plano peržiūra, skirtingų sveikatos priežiūros lygių bendradarbiavimu ${ }^{19}$. Ivairių tyrimų duomenimis, nuo-

17 Muenchberger, H.; Kendall, E. Predictors of preventable hospitalization in chronic disease: Priorities for change. Journal of Public Health Policy. 2010, 32(2): 150-163.

18 Health Outcomes Section, Development and Resources Branch, Public Health Division, supra note 1 .

19 Katterl, R., et al., supra note 9, p. 21. 
tolinès (telemedicinos) priemonėmis teikiamos konsultacijos pasirodė ypatingai veiksmingos mažinant $\mathrm{IH}$ skaičių ${ }^{20}$.

Apibendrinus kitose šalyse sukauptas žinias tampa aišku, kad IH problemą galima spręsti ịvairiomis priemonėmis, o tai padètų sumažinti išlaidas, skiriamas stacionarinei sveikatos priežiūrai. Sutaupytas lèšas, skirtas stacionarinėms paslaugoms apmokèti, būtų galima panaudoti kitur (pavyzdžiui, gydytojų kvalifikacijai kelti, darbo užmokesčiui didinti, infrastruktūrai gerinti ir kt.).

Didžioji dalis sveikatos priežiūros paslaugų Lietuvoje apmokamos iš Privalomojo sveikatos draudimo fondo biudžeto, kuris buvo, yra ir bus ribotas, o hospitalizacijų rodikliai 1,5 karto viršija ES vidurkị. Dèl šių priežasčių IH pasirinkome savo tyrimo objektu, o šios publikacijos tikslas yra įvertinti IH situaciją Lietuvoje $2012 \mathrm{~m}$. ir pasiūlyti galimus problemos sprendimo būdus. Šiam tikslui pasiekti buvo numatyti keli uždaviniai: 1) nustatyti, kokie pacientai pagal amžių, lytị ir gyvenamąją vietovę ir dèl kurių AVL dažniausiai hospitalizuojami; 2) išanalizuoti dažniausias AVL grupes pagal atvykimo į stacionarą tipą; 3) nustatyti IH teritorinius skirtumus; 4) pasiūlyti prioritetines kryptis sumažinti IH skaičių Lietuvoje.

\section{Tyrimo metodika}

Tyrimas įvykdytas atliekant turimų oficialių statistinių duomenų analizę. AVL sąrašas ir hospitalizacijų atvejai atrinkti remiantis Australijoje taikoma metodika. Ši metodika buvo pritaikyta visai šaliai po $2002 \mathrm{~m}$. atlikto tyrimo Viktorijos regione ir tobulinama jau daugiau nei dešimtmetị ${ }^{21}$, nuolat atnaujina$\mathrm{ma}^{22}$. Metodikoje ịvardinti rodikliai rodo, ar ambulatorinè sveikatos priežiūra yra teikiama efektyviai, tinkamai ir laiku. Rodikliai šaliai ir atskiriems administraciniams vienetams skaičiuojami naudojantis oficialia Australijos statistika. Australijoje naudojama TLK-10-AM ligų klasifikacija, kuri nuo 2011 m. ịdiegta ir Lietuvoje. Tokios metodikos savybės sudaro puikias galimybes kuo mažiau keičiamą originalią metodiką panaudoti Lietuvos IH rodikliams skaičiuoti.

IH suskaičiuoti Lietuvoje panaudoti TLK-10-AM ligų kodai, suskirstyti i 21 AVL grupę $e^{23,24}$ (atmetus hospitalizacijas pagal tam tikrus TLK-10-AM ligu arba ACHI procedūrų kodus).

20 Basu, A.; Brinson, D. The effectiveness of interventions for reducing ambulatory care sensitive hospitalisations: a systematic review. HSAC Report. 2008, 1(6).

${ }^{21}$ Health Outcomes Section, Development and Resources Branch, Public Health Division, supra note 1 .

22 Australian Institute of Health and Welfare. Primary and Community Health [interaktyvus]. Metadata Online Registry, 2015 [žiūrèta 2015-02-10]. <http://meteor.aihw.gov.au/content/index. $\mathrm{phtml} /$ itemId/393484>.

23 Australian Institute of Health and Welfare. National Healthcare Agreement: PI 22-Selected potentially preventable hospitalisations, 2012 [interaktyvus]. Metadata Online Registry, 2015 [žiūrèta 2015-02-10]. <http://meteor.aihw.gov.au/content/index.phtml/itemId/443687>.

24 Mekšriūnaitè S.; Gurevičius R. Išvengiamų hospitalizacijų mastas Lietuvoje 2012 metais: bendra apžvalga. Visuomenés sveikata. 2014, 4(67): 26-35. 
Tyrimo populiaciją sudarè visi Lietuvos gyventojai, $2012 \mathrm{~m}$. hospitalizuoti dèl AVL (ịtraukti atvejai, kurių hospitalizacijos pabaiga buvo $2012 \mathrm{~m}$.). Informacijos šaltiniai:

- hospitalizacijų duomenys gauti iš Privalomojo sveikatos draudimo informacinès sistemos „Sveidra“, kurioje kaupiami stacionare gydomų asmenu statistinès kortelès (forma Nr. 066/a-LK ${ }^{25}$ ) duomenys (pagrindinè diagnozé, gretutiné diagnozé, lytis, gyvenamoji vietovė, atvykimo tipas, hospitalizavimo trukmé, atvejo tipas);

- 2012 ir 2013 m. pradžios gyventojų skaičių pagal lytị, amžių, gyvenamąją vietovę gavome iš Lietuvos statistikos departamento duomenų bazių.

Atmetėme hospitalizacijos atvejus pagal hospitalizacijos tipą: medicininę reabilitaciją, ilgalaikị gydymą ir dienos stacionaro atvejus. Apskaičiavome IH procentinę struktūrą pagal AVL grupes, IH skaičių 1000 gyventojų ir 1000 hospitalizacijų. Pritaikę Pareto dėsnị (80 proc.) išskyrème didžiausią IH dalị sudarančias AVL grupes ir atlikome aprašomąją analizę pagal amžių, lytį, gyvenamąją vietovę, hospitalizavimo trukmę. Lygindami IH skaičių, tenkantị 1000 gyv., savivaldybėse pagal lytị ir gyvenamąją vietovę rodiklį standartizavome naudodami Lietuvos gyventojų amžiaus struktūrą (2011 m. vidutinis metinis gyventojų sk.).

IH rodiklių skirtumams pagal lytị ir gyvenamąją vietovę įvertinti naudojome $\chi^{2}$ testą. Hospitalizuotų asmenų amžiui palyginti panaudojome Mann-Whitney U, arba Wilcoxono, testą (dviem grupėms palyginti), kadangi šių kintamųjų skirstiniai skyrèsi nuo normalaus. Vyrų ir moterų IH skaičiaus 1000 gyv. koreliacija savivaldybėse nustatyta naudojant Pearsono koreliacijos testą. Pasirinktas statistinio reikšmingumo lygmuo $\mathrm{a}=0,05$.

\section{IH būklès Lietuvoje $2012 \mathrm{~m}$. analizè}

\subsection{IH analizè pagal mastą ir ligas}

Lietuvoje 2012 m. iš viso buvo $110856 \mathrm{IH}$ (16,2 proc. visų aktyvaus gydymo stacionaro atvejų). Pagal Pareto dėsni (80 proc.) nustatyta, kad didžiausią IH dalị sudarè hospitalizacijos dèl šių AVL grupių (1 lentelè): cukrinio diabeto ir jo komplikacijų, krūtinès anginos, stazinio širdies nepakankamumo, gripo ir pneumonijos, ausų, nosies ir gerklès infekcijų, lètinès obstrukcinès plaučių ligos (LOPL) ir pielonefrito. Išvardintos ligos sudarė 5,8-17,9 proc. visų IH. Jų rodikliai svyravo nuo 2,2 iki 6,6 atvejų 1000 gyventojų (arba nuo 9,4 iki 28,9 atveju 1000 aktyvaus gydymo stacionaro atvejų).

25 LR sveikatos apsaugos ministro 2011 m. gegužès 26 d. ̨̣sakymas Nr. V-532 „Dèl Lietuvos Respublikos sveikatos apsaugos ministro $1998 \mathrm{~m}$. lapkričio $26 \mathrm{~d}$. ̨̣sakymo Nr. 687 „Dél medicininès apskaitos dokumentų formų tvirtinimo“ pakeitimo“. Valstybès žinios. 2011, Nr. 65-3053. 
1 lentelè. IH paplitimas ir struktūra pagal AVL grupes Lietuvoje 2012 m.

\begin{tabular}{|l|c|c|c|c|}
\hline \multicolumn{1}{|c|}{ AVL grupe } & $\begin{array}{c}\text { Iš viso IH } \\
\text { (abs. sk.) }\end{array}$ & $\begin{array}{c}\text { IH dalis } \\
\text { (proc.) }\end{array}$ & $\begin{array}{c}\text { IH / } \\
1000 \text { gyv. }\end{array}$ & $\begin{array}{c}\text { IH / 1000 hos- } \\
\text { pitalizacijų }\end{array}$ \\
\hline Visos AVL & 110856 & 100,0 & 37,1 & 161,8 \\
\hline Cukrinis diabetas ir jo komplikacijos & 19800 & 17,9 & 6,6 & 28,9 \\
\hline Krūtinés angina & 17873 & 16,1 & 6,0 & 26,1 \\
\hline Stazinis širdies nepakankamumas & 15321 & 13,8 & 5,1 & 22,4 \\
\hline Gripas ir pneumonija & 13202 & 11,9 & 4,4 & 19,3 \\
\hline Ausų, nosies ir gerklès infekcijos & 9830 & 8,9 & 3,3 & 14,4 \\
\hline LOPL & 8447 & 7,6 & 2,8 & 12,3 \\
\hline Pielonefritas & 6469 & 5,8 & 2,2 & 9,4 \\
\hline Hipertenzija & 5877 & 5,3 & 2,0 & 8,6 \\
\hline Priepuoliai, epilepsijos, konvulsijos & 4284 & 3,9 & 1,4 & 6,3 \\
\hline Astma ir astminè būkle & 3475 & 3,1 & 1,2 & 5,1 \\
\hline Dehidratacija ir gastroenteritas & 3050 & 2,8 & 1,0 & 4,5 \\
\hline Perforuota, kraujuojanti opa & 2905 & 2,6 & 1,0 & 4,2 \\
\hline Burnos, dantų ligos & 1746 & 1,6 & 0,6 & 2,6 \\
\hline Moters dubens organų uždegiminès ligos & 1417 & 1,3 & 0,5 & 2,1 \\
\hline Geležies stokos anemija & 1167 & 1,1 & 0,4 & 1,7 \\
\hline Celiulitas & 914 & 0,8 & 0,3 & 1,3 \\
\hline $\begin{array}{l}\text { Umus apendicitas su generalizuotu } \\
\text { peritonitu }\end{array}$ & 621 & 0,6 & 0,2 & 0,9 \\
\hline Kitos skiepais išvengiamos ligos & 421 & 0,4 & 0,1 & 0,6 \\
\hline Reumatinės širdies ligos & 429 & 0,4 & 0,1 & 0,6 \\
\hline Mitybos nepakankamumas & 31 & 0,03 & 0,01 & 0,1 \\
\hline Gangrena & 30 & 0,03 & 0,01 & 0,04 \\
\hline
\end{tabular}

IH rodikliai skyrèsi pagal lytị, gyvenamąją vietovę ir amžių. Vyrų IH rodiklis (42,2 atv. /1000 gyv.) buvo didesnis nei moteru (33,7 atv. /1000 gyv.), kaimo gyventoju (39,5 atv. /1000 gyv.) didesnis nei miesto gyventojų (36,4 atv. /1000 gyv.). Hospitalizuojamos moterys ir kaimo gyventojai buvo vyresnio amžiaus nei vyrai ir miesto gyventojai.

Dažniausiai dèl AVL buvo hospitalizuojami vaikai, ypač ikimokyklinio amžiaus, bei pensinio amžiaus asmenys (2 lentelè). Ikimokyklinio amžiaus vaikų paamžinis IH rodiklis $2012 \mathrm{~m}$. svyravo nuo 20,0 iki 113,2 atv. / 1000 gyv., o pensinio amžiaus asmenų - nuo 60,6 iki 185,4 atv. / 1000 gyv. Darbingo amžiaus asmenų (18-64 m.) IH rodiklis svyravo nuo 7,0 iki 57,1 atv. / 1000 gyv.

Senstant paamžinis IH rodiklis didejo dèl cukrinio diabeto ir jo komplikacijų, krūtinès anginos, stazinio širdies nepakankamumo. Vaikams buvo labai 
aktualios hospitalizacijos dèl ausų, nosies ir gerklès infekcijų (vaikų IH dèl šios priežasties sudare 83,6 proc. visų IH dèl šios AVL). Vaikų ir pensinio amžiaus gyventojų pielonefrito $\mathrm{IH}$ rodikliai buvo panašūs, tačiau $1 \mathrm{~m}$. amžiaus vaikų $\mathrm{IH}$ rodiklis dèl šios ligos buvo ypatingai didelis (12,5 atv. / 1000 gyv.). Pensinio amžiaus gyventojų IH rodikliai dèl gripo ir pneumonijos bei LOPL buvo didesni nei vaikų, tačiau abiejose amžiaus grupèse užfiksuoti tam tikri rodiklių pikai:

- 1 m. amžiaus vaikai: IH dèl LOPL - 6,3 atv. / 1000 gyv.;

- 2-3 m. amžiaus vaikai: IH dèl gripo ir pneumonijos - 11,6 atv. / 1000 gyv.;

- 85 m. ir vyresni asmenys: IH dèl gripo ir pneumonijos - 26,6 atv. / 1000 gyv.;

- 85 m. ir vyresni asmenys: IH dèl LOPL - 17,2 atv. / 1000 gyv.

Apibendrinant pasakytina, kad IH rodikliai dèl ausų, nosies ir gerklès infekcijų, pielonefrito bei gripo ir pneumonijos 1-4 m. amžiaus vaikų grupeje išsiskyrẻ iš kitų vaikų kelis kartus didesniais rodikliais.

2 lentelè. IH dèl dažniausių AVL rodikliai 1000 gyv. pagal amžiaus grupes

\begin{tabular}{|l|c|c|c|}
\hline \multicolumn{1}{|c|}{ AVL grupès } & $0-17 \mathrm{~m}$. & $18-64 \mathrm{~m}$. & $65+\mathrm{m}$. \\
\hline Visos AVL & 41,9 & 18,2 & 110,1 \\
\hline Cukrinis diabetas ir jo komplikacijos & 1,2 & 3,9 & 21,6 \\
\hline Krūtinès angina & 0,0 & 2,8 & 23,3 \\
\hline Stazinis širdies nepakankamumas & 0,0 & 1,3 & 23,6 \\
\hline Gripas ir pneumonija & 4,7 & 2,0 & 12,4 \\
\hline Ausų, nosies ir gerklès infekcijos & 16,0 & 0,5 & 0,2 \\
\hline LOPL & 2,0 & 0,9 & 10,4 \\
\hline Pielonefritas & 3,4 & 1,2 & 4,4 \\
\hline
\end{tabular}

\subsection{IH analizė pagal atvykimo ị stacionarą būdą}

Dažniausiai į stacionarą dèl IH buvo atvykstama su siuntimu $(62,0$ proc. atvejų). Daugiau nei penktadalis (22,7 proc.) hospitalizuotų ligonių buvo atvykę su greitąja medicinos pagalba (GMP), o likusios hospitalizacijos buvo be siuntimo atvykus pačiam pacientui ( 15,3 proc.).

Pagal atvykimo ị stacionarą būdą toliau atskirai nagrinejome 7 dažniausias AVL. IH pagal atvykimo tipą buvo pasiskirsčiusios panašiai, išskyrus dvi AVL grupes: cukrinį diabetą ir jo komplikacijas bei ausų, nosies ir gerklès infekcijas (1 pav.). 


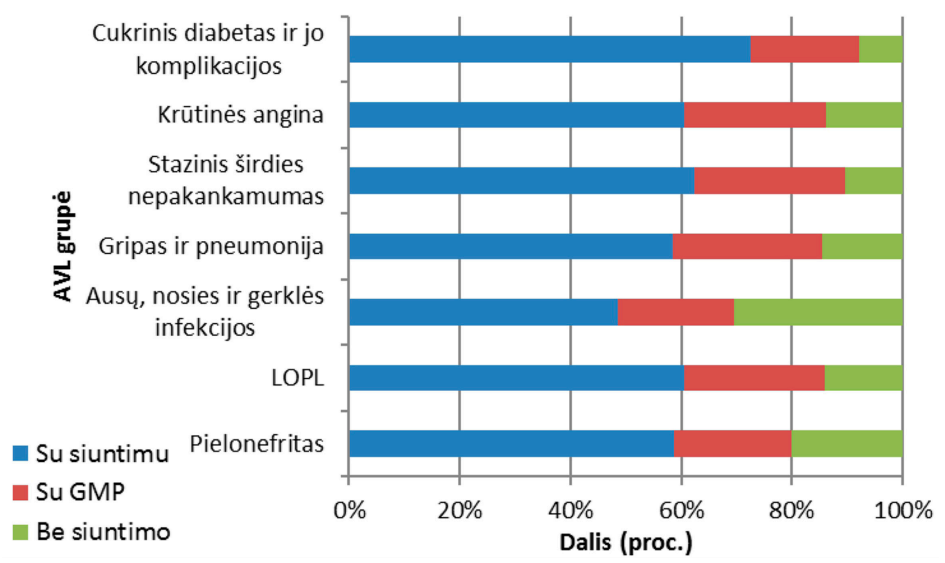

1 pav. Dažniausių AVL struktūra pagal atvykimo tipą (dalis procentais nuo visų atvykimų dèl konkrečios AVL) Lietuvoje $2012 \mathrm{~m}$.

Dažniausiai, apie 60 proc., dèl AVL atvykdavo su siuntimu, apie 21-27 proc. atvyko su GMP, o kiti - be siuntimo. Cukrinis diabetas ir jo komplikacijos išsiskyrè tuo, jog net 72,5 proc. atvykusiųjų turejo siuntimus, tik 7,8 proc. atvyko be siuntimo, o 19,6 proc. - su GMP. Ausų, nosies ir gerklès infekcijos buvo vienintele AVL grupè, kurios asmenys dažniau buvo hospitalizuojami be siuntimo (30,5 proc.) nei atvykę su GMP (21,0 proc.). Mažiau nei pusè šios AVL grupès hospitalizuotųjų turèjo siuntimus (30,8 proc.).

\subsection{IH analizė pagal savivaldybes}

IH rodikliai šalies savivaldybėse $2012 \mathrm{~m}$. svyravo nuo 27 iki 57,7 atv. / 1000 gyv. (2 pav.). Didžioji dalis savivaldybių IH rodiklių buvo didesni nei Lietuvos vidurkis (36,5 atv. / 1000 gyv.). Tik dviejose savivaldybėse (Vilniaus m. ir Vilniaus r.) IH rodikliai neviršijo 30 atv. / 1000 gyv., o keturiose - viršijo 50 atv. / 1000 gyv. (Akmenès r., Visagino, Anykščių r. ir Zarasų r.).

Anykščių r. sav. didžiausi IH rodikliai buvo dèl stazinio širdies nepakankamumo, Zarasų r. sav. - dèl gripo ir pneumonijos bei hipertenzijos, Akmenės r. sav. dèl gripo ir pneumonijos bei ausų, nosies ir gerklès infekcijų. Akmenės r. sav. IH dèl cukrinio diabeto ir jo komplikacijų rodiklis buvo mažesnis už Lietuvos vidurkį. Visagino sav. didžiausi IH rodikliai buvo dèl hipertenzijos bei cukrinio diabeto ir jo komplikacijų. Vilniaus $\mathrm{m}$. ir Vilniaus r. sav. IH rodikliai dél dažniausių Lietuvoje AVL buvo mažesni už vidutinius šalies rodiklius, tačiau pagrindinès IH priežastys šiose savivaldybèse buvo tokios pačios kaip Lietuvos 
mastu - cukrinis diabetas ir jo komplikacijos, krūtinès angina ir stazinis širdies nepakankamumas.

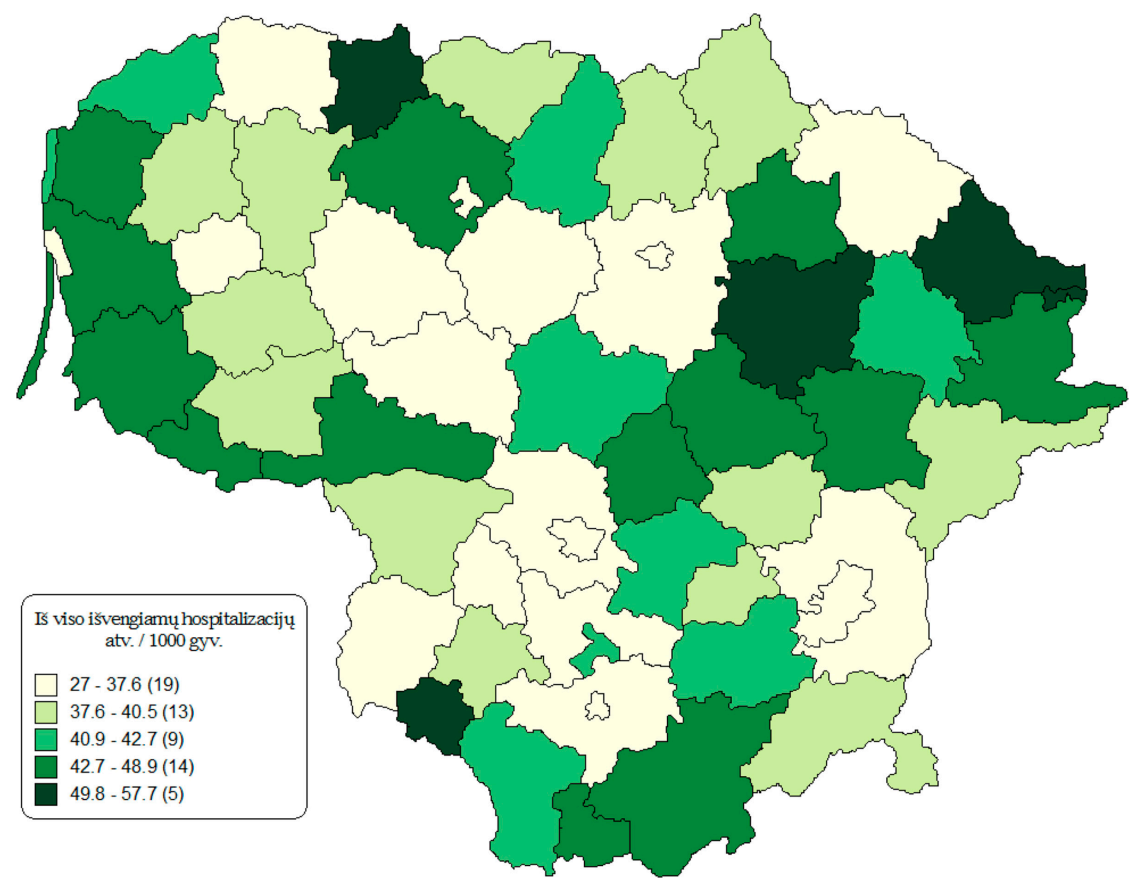

2 pav. IH skaičius, tenkantis 1000 gyv., Lietuvos savivaldybėse 2012 m.

Tarp vyrų ir moterų IH rodiklių savivaldybėse nustatytas stiprus koreliacinis ryšys $\left(\mathrm{r}=+0,72 ; \mathrm{r}^{2}=54,8\right.$ proc.; $\left.\mathrm{p}<0,01\right)$. Tokia koreliacija rodo, jog savivaldybe்se, kuriose yra aukštas vyrų IH rodiklis, taip pat yra aukštas moterų IH rodiklis, ir atvirkščiai (3 pav.). Atsižvelgiant ị rodiklių medianas ir taškinès diagramos taškų išsidėstymą, matoma bendra tendencija, kad vyrų IH rodikliai dažniausiai yra didesni nei moterų. 


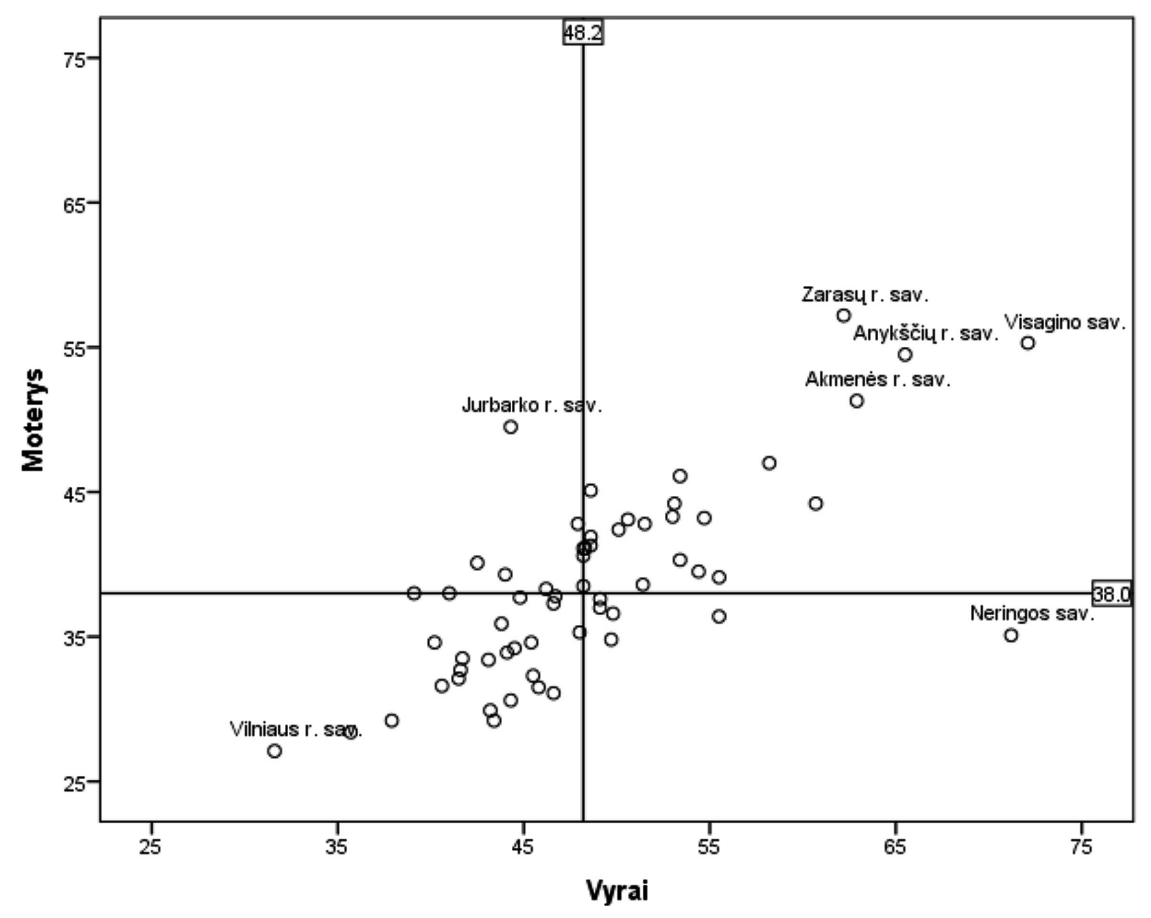

3 pav. Vyrų ir moterų IH rodiklių 1000 gyv. palyginimas savivaldybėse $2012 \mathrm{~m}$. (vertikali ir horizontali linijos žymi IH rodiklių medianas)

\section{Rezultatų aptarimas}

Apibendrinant tyrimo rezultatus sudètinga lyginti juos su kitomis šalimis, nes taikomos skirtingos metodikos IH rodikliams skaičiuoti. Tyrimo rezultatai praktiškai palyginami tik su Australijos IH rodikliais, kuriems apskaičiuoti panaudotas toks pats AVL ir TLK-10-AM ligų kodų sąrašas, kurị naudojome savo tyrime, tačiau šis palyginimas galimas tik iki 2012 m., nes vèliau AVL TLK-10AM ligų kodai Australijoje buvo koreguojami kiekvienais metais ${ }^{26}$.

Paskutiniai oficialiai pateikiami Australijos duomenys yra 2009-2010 m., kurie suskaičiuoti naudojant tokius pačius TLK-10-AM kodus kaip ir mūsų tyrime. Minètų metų duomenimis, Australijoje cukrinis diabetas ir jo komplikacijos buvo pirmoje vietoje AVL struktūroje ir sudare 23,9 proc. visų IH, kurių buvo 695,5 tūkst. atvejų. Kitos AVL, kurios, mūsų tyrimo duomenimis, yra

26 Australian Institute of Health and Welfare, supra note 22. 
svarbios Lietuvai, Australijos IH struktūroje išsidèstė labai nevienodai (krūtinès angina sudare 4,8 proc., stazinis širdies nepakankamumas $-6,6$ proc., gripas ir pneumonija - 2,0 proc., ausų, nosies ir gerklès infekcijos - 5,0 proc., LOPL 8,9 proc., pielonefritas - 8,0 proc.). Australijoje, palyginti su mūsų tyrimo duomenimis, buvo svarbios IH dèl dehidratacijos ir enterito (9,5 proc.), dantų ir burnos ligų ( 8,7 proc.), celiulito (5,8 proc.) ir astmos $(5,6 \text { proc. })^{27}$. Tad krūtinès angina Australijoje nèra tokia aktuali kaip Lietuvoje, tačiau Lietuvoje mums nèra tokios aktualios kaip Australijoje IH dèl dehidratacijos ir gastroenterito, dantu ligų, celiulito ir astmos. Tokius Lietuvos ir Australijos IH skirtumus galejjo lemti labai daug individualių ar valstybinio lygio priežasčių: prevencinė veikla, ypač vakcinacija, ambulatorinès sveikatos priežiūros prieinamumas, gydymo praktika, gyventojų sveikatos elgsena, klimatinès sąlygos ir kitos priežastys.

Viena iš galimų priežasčių - gyventojų amžiaus struktūros skirtumai. Juos ịvertinti būtų galima tik žinant standartizuotus pagal amžių IH rodiklius abiejose šalyse. Deja, Australija ir kitos šalys nestandartizuoja IH rodiklių pagal visuotinai priimtus standartus (pavyzdžiui, Europos ar pasaulio standartinę populiaciją), t. y. nesiekiama šalies IH rodiklių lyginti su kitų šalių rodikliais. Jei IH rodikliai šalyse standartizuojami, tai tam naudojami pasirinkti vidiniai, šalies gyventojų amžiaus struktūros standartai. Tai galima paaiškinti ir tuo, kad šalys naudoja skirtingus AVL sąrašus ir rodiklių skaičiavimo metodikas, todèl netgi standartizuoti rodikliai būtų mažai palyginami.

Visais atvejais atlikti tyrimai neleidžia abejoti amžiaus įtaka IH skaičiui ${ }^{28,29}$. Didžiausi IH rodikliai yra vaikų (ypač naujagimių) ir vyresnių nei $65 \mathrm{~m}$. amžiaus asmenų $u^{30}$. Mūsų tyrimo rezultatai rodo, kad Lietuvoje tendencija tokia pati. Žinoma, vaikų IH rodikliai gali būti didesni dẻl to, kad jie yra jautresné pacientų grupè, ypač dẻl infekcinių ligų. Pensinio amžiaus asmenų IH rodikliai tikriausiai didesni dèl dažnų kitų ligų. Kartu iš praktikos žinoma, kad gydytojai neretai pacientus, ypač vaikus ar sergančius keliomis ligomis, gali hospitalizuoti apsidrausdami, o vyresnio amžiaus pacientai nevengia būti hospitalizuoti, kad nebūtų vieni namuose. Taip pat kai kurie pacientai patys reikalauja būti paguldyti ¡̇ ligoninę, nors tai ne visada yra būtina ${ }^{31}$. Iš kitos pusès, maži darbingo amžiaus asmenų IH rodikliai gali būti dèl socialinès apsaugos politikos - darbingi žmonès labiau linkę atsisakyti gultis ị ligoninę ir gauti nedarbingumo pažymèjimą. Vaikams ir pensinio amžiaus asmenims tai ne taip aktualu.

Katterl, R., et al., supra note 9, p. 13.

28 Ibid., p. 11.

29 Guo, L., et al. How are age and payors related to avoidable hospitalization conditions? Managed care quarterly. 2001, 9(4): 33-42.

$30 \quad$ Katterl, R., et al., supra note 9, p. 11.

31 Freund, T., et al. Strategies for Reducing Potentially Avoidable Hospitalizations for Ambulatory Care-Sensitive Conditions. Annals of Family Medicine. 2013, 11(4): 363-370. 
Ivairių tyrimų rezultatai rodo, kad dažniausiai vyrų IH rodikliai yra didesni nei moterų, kaip ir mūsų atliktame tyrime, išskyrus atvejus, kai gali būti lyginami skirtingų AVL hospitalizacijų rodikliai pagal lytį ${ }^{32,33}$. Toks reiškinys gali būti paaiškinamas skirtingu vyrų ir moterų elgesiu: moterys yra linkusios dažniau lankytis pas šeimos gydytoją nei vyrai, todèl didesnè tikimybè, kad jos bus pakankamai prižiūrètos ambulatoriškai ir nereikès gultis ị ligoninę. Taip pat moterys gali būti linkusios dažniau atsisakyti gultis ị ligoninę nei vyrai dèl jų laukiančių pareigų namuose (vaikų priežiūra, namų ūkis ir kt.).

Nèra iki galo aišku, kokią įtaką gyvenamoji vietovẻ daro IH skaičiui, nes tyrimų rezultatai prieštaringi. Kai kurių tyrimų duomenimis, kuo toliau pacientai gyvena nuo ligoninès, tuo mažiau jų hospitalizuojama. Taip pat kai kur pastebėta, kad IH rodikliai buvo didžiausi pacientų, kurie gyveno labai arti arba labai toli nuo ligoninès, o gyvenusių vidutiniu atstumu nuo ligoninès IH rodikliai buvo mažiausi. Kiti tyrimai rodo, kad kaimo gyventojai hospitalizuojami dažniau (kaip 2012 m. Lietuvoje). Mūsų manymu, atstumas nuo ligoninès labiau lemia paties asmens apsisprendimą gultis ị ligoninę stacionariniam gydymui nei gydytojo sprendimą dèl hospitalizacijos reikalingumo. IH atveju reikètų analizuoti ne tik kaip toli pacientas gyvena nuo ligoninès, bet ir kokiu atstumu jam pasiekiamas šeimos gydytojas.

Mūsų tyrime nenagrinèti, tačiau iš ankstesnių užsienio publikacijų žinomi kiti veiksniai, kurie daro didelę ittaką IH rodikliams ${ }^{34,35}$. Žema socialinè-ekonominė gyventojų padėtis siejama su didesniais IH rodikliais ir šis ryšys ypač stipriai pastebimas tarp vyresnio amžiaus asmenų. Tiketina, jog labiau pasiturintys asmenys labiau linkę saugoti savo sveikatą, jie gali leisti sau geresnes sveikatos priežiūros paslaugas, jiems kyla mažiau problemų nuvykti pas šeimos gydytoją. Tačiau visi anksčiau išvardinti veiksniai, darantys įtaką IH skaičiui, yra beveik koreguojami per ambulatorinès sveikatos priežiūros paslaugų teikimą.

Paskelbti tyrimai rodo, kad IH tikimybè padideja, jeigu asmuo buvo hospitalizuotas anksčiau ${ }^{36}$. Šis ryšys yra ypatingai išreikštas nagrinejjant hospitalizacijas dèl kvejpavimo takų ligų. Dèl šios priežasties gali būti svarbu šalyje stebėti pakartotinių IH rodiklius, kurie apibūdintų ne tik ambulatorinės, bet ir stacionarinės sveikatos priežiūros paslaugų kokybę bei jų tarpusavio bendradarbiavimą ${ }^{37}$.

\footnotetext{
32 Katterl, R., et al., supra note 9, p. 11.

33 Rizza, P., et al. Preventable hospitalization and access to primary health care in an area of Southern Italy. BMC Health Services Research. 2007, 7: 134-142.

34 Katterl, R., et al., supra note 9, p. 11-12.

35 Health Outcomes Section, Development and Resources Branch, Public Health Division. Supra note 1, p. 1-2.

36 Maslow, K.; Ouslander, J. G., supra note 4, p. 39.

37 Institute for Healthcare Improvement. Readmissions. Reduce Avoidable Readmissions [interaktyvus]. Cambridge, 2015 [žiürèta 2015-02-11]. <http://www.ihi.org/topics/readmissions/Pages/default.aspx>.
} 
Taip pat žinoma, kad didesnis šeimos gydytojų skaičius yra susijęs su mažesniais IH rodikliais ${ }^{38}$, o didesnis ligoninès lovų skaičius didina tikimybę, kad IH rodikliai bus didesni (nors ligoninès lovų ir IH ryšiui pagrịsti vis dar trūksta stipresnių ịrodymų) $)^{39}$. Kadangi Lietuvoje turime patikimą statistiką apie gydytojų ir ligoninès lovų skaičių, tai šių veiksnių ryšio su IH skaičiumi nustatymas gali būti tolesnių tyrimų šalyje dalis. Tik dèl skirtingo ambulatorinès sveikatos priežiūros vaidmens mažinant ūmių ir lètinių AVL skaičių verta jas nagrinèti

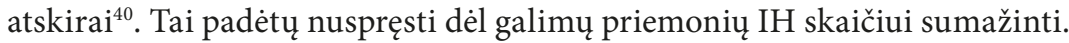

Kai kuriuose tyrimuose apžvelgiama sveikatos priežiūros tęstinumo įtaka IH skaičiui. Rezultatai rodo, kad integruotos paslaugos ir sveikatos priežiūros koordinavimas daro nedidelę ar vidutinę įtaką IH skaičiui ${ }^{41,42}$. Šiuo metu, kai Lietuvoje dar tik pradedamos diegti integruotos sveikatos priežiūros paslaugos ${ }^{43}$, reiktų atsižvelgti ir į galimybę sumažinti IH skaičių per teikiamų paslaugų spektrą, kokybę ir tęstinumą.

Literatūroje IH mažai aptariamos pagal atvykimo tipą. Mūsų tyrimo duomenimis, daugiausiai pacientai dèl AVL hospitalizuojami su gydytojo siuntimu, vadinasi, jie pereina ambulatorinès sveikatos priežiūros „filtrą“. Su gydytojo siuntimu ypač dažnai hospitalizuojami pacientai, sergantys cukriniu diabetu ir jo komplikacijomis. Kaip žinoma, ši lètinẻ liga yra nesunkiai kontroliuojama ambulatorinemis sąlygomis. Tai ne taip aktualu pacientams, hospitalizuotiems dèl ausų, nosies ir gerklès infekcijų, kurių puse i stacionarą atvyksta su GMP arba patys be siuntimo ir kurių būkle greičiausiai būna tiek pablogejusi, kad ambulatorinis gydymas jau nebepadètų ${ }^{44}$. Apskritai hospitalizacijos be siuntimo ar atvykus su GMP gali įspèti apie prastesnị ambulatorinès sveikatos priežiūros prieinamumą, kurį galima nagrinèti atskirose savivaldybėse.

Prieinamumą taip pat rodo visos ūmios AVL. Dèl ịvairių priežasčių pacientai, pajutę pirmuosius ligos simptomus, iškart nesikreipia ị gydytojus, kol jų sveikatos būklè greitai ir smarkiai pablogèja tiek, kad juos būtina guldyti ị ligoninę. Nesikreipimo priežastys gali būti ịvairios: simptomų nuvertinimas, prastos galimybės skubiai nuvykti pas gydytoją, asmens sveikatos priežiūros ịstaigos ar

38 Parchman, M. L.; Culler, S. Primary care physicians and avoidable hospitalizations. The Journal of Family Practice. 1994, 39(2): 123-128.

$39 \quad$ Katterl, R., et al., supra note 9, p. 12.

40 Rosano, A., et al. Hospitalization for ambulatory care sensitive conditions and the role of primary care in Italian regions. Italian Journal of Public Health. 2011, 8(1): 77-88.

${ }^{41}$ Fill, J. M.; Mainous, A. G. The role of provider continuity in preventing hospitalizations. Archives of Family Medicine. 1998, 7(4): 352-357.

$42 \quad$ Katterl, R., et al., supra note 9, p. 12.

43 LR sveikatos apsaugos ministerija. Vyriausieji SAM respublikos specialistai pritare integruotos sveikatos priežiūros igyvendinimo planui [interaktyvus]. Vilnius, 2013 [žiūrèta 2015-02-11]. <http:// www.sam.lt/go.php/lit/Vyriausieji-SAM-respublikos-specialistai-pritare-integruotos-sveikatosprieziuros-igyvendinimo-planui>.

44 Freund, T., et al., supra note 31. 
gydytojų nenoras priimti pacientą be eilès, budinčio šeimos gydytojo nebuvimas (ne darbo valandomis) ${ }^{45}$. Mūsų šalyje kaip ambulatorinių sveikatos priežiūros paslaugų prieinamumą mažinantị veiksnị galima išskirti ir kvotuotas paslaugas $^{46}$. Šioms nesikreipimo ir mažo prieinamumo priežastims galima daryti ịtaką sveikatos priežiūros vadybos priemonèmis ir pacientų mokymu.

Remiantis 2012 m. duomenimis, Lietuvoje nustatyti IH rodiklių skirtumai tarp savivaldybių. Pastebima, kad mažesni IH rodikliai daugiausiai buvo didžiosiose savivaldybėse: Vilniaus m., Vilniaus r., Kauno r., Šiaulių m., Alytaus r., Klaipėdos m., Panevėžio r., Kauno m. Tikètina, kad mažesnị IH rodiklị didesnèse savivaldybėse galèjo lemti geresnè ambulatorinejje grandyje dirbančiu gydytojų kvalifikacija, didesnès tobulinimosi galimybės arba, atvirkščiai, didesnị IH rodiklị mažesnèse savivaldybėse galëjo lemti šeimos gydytojų trūkumas jose ${ }^{47}$. Dèl šios priežasties priemonès, gerinančios darbo sąlygas mažesnėse savivaldybėse, galètų prisidèti prie IH rodiklių mažinimo. Kartu reikètų nepamiršti sudaryti palankias sąlygas gydytojams kelti kvalifikaciją, ypač kontroliuojant lètines ligas. Žinoma, neatmetama galimybė, kad kai kuriose savivaldybėse IH rodikliai gali būti didesni dèl prastesnès gyventojų socialinės-ekonominès padèties (nedarbo, mažo darbo užmokesčio, prastų gyvenimo sąlygų).

IH problemą atskirose savivaldybėse rodo ir vyrų bei moterų IH rodiklių koreliacija. Tai, kad vyrų IH rodikliai yra aukšti tose savivaldybėse, kuriose yra aukšti moterų IH rodikliai, rodo, jog problemos yra sisteminės, lokalizuotos savivaldybejje ir tai daro įtaką abiejų lyčių IH rodikliams. Panašūs skirtumai tarp teritorinių vienetų pastebėti kitose šalyse (Ispanijoje ${ }^{48}, \mathrm{JAV}^{49}$, Australijoje ${ }^{50}$ ). Tai, kad kai kuriose savivaldybėse skiriasi dažniausios AVL, rodo galimus gydytojų pasiskirstymo, teikiamų paslaugų netolygumus. Tačiau tam nustatyti reikia atlikti platesnę analizę.

\section{Rekomendacijos}

Atlikus vienerių metų IH rodiklių analizę pradeda ryškèti potencialios veiksmų kryptys ir probleminès savivaldybės. Tačiau norint gauti išsamesnès ir tiks-

45 Freund, T., et al., supra note 31.

46 V. P. Andriukaitis: „Virškvotiniu paslaugu sveikatos priežiūros sistemoje turi nelikti“ [interaktyvus]. Vaistai.lt, 2013 [žiūrèta 2015-02-12]. <http://www.vaistai.lt/V-P-Andriukaitis-Virskvotiniu-paslaugu-sveikatos-prieziuros-sistemoje-turi-nelikti-2147.html>.

47 LR sveikatos apsaugos ministerija. Savivaldybiu gydytojai siunčia signalus apie dramatiška specialistu poreikị rajonuose [interaktyvus]. Vilnius, 2013 [žiūrèta 2015-02-11]. <http://www.sam.lt/go.php/lit/ Savivaldybiu-gydytojai-siuncia-signalus-apie-dramatiska-specialistu-poreiki-rajonuose $>$.

48 Magan, P., et al., supra note 16.

49 Segal, M., et al. Medicare-Medicaid Eligible Beneficiaries and Potentially Avoidable Hospitalizations. Medicare \& Medicaid Research Review. 2014, 4(1).

50 Page, A., et al. Atlas of Avoidable Hospitalisations in Australia: ambulatory care-sensitive conditions. Adelaide: PHIDU, University of Adelaide, 2007. 
lesnès informacijos apie galimus veiksmus IH rodiklius reikia stebėti nuolatos. Šiam tikslui LR sveikatos apsaugos ministro $2014 \mathrm{~m}$. gruodžio $12 \mathrm{~d}$. i̇sakymu Nr. V-1313 buvo sudaryta darbo grupe išvengiamos hospitalizacijos rodikliu skaičiavimo metodikai parengti. Šia metodika bus skaičiuojami kasmetiniai IH rodikliai, atliekama IH rodiklių analizè ir pateikti pasiūlymai sumažinti IH skaičių.

Tikimasi, kad patvirtinta IH rodiklių skaičiavimo metodika padės atsirinkti prioritetines veiksmų kryptis ir sumažinus IH skaičių bus sutaupyta Privalomojo sveikatos draudimo fondo lèšų, kurias galèsime skirti kitoms sveikatos priežiūros ar gyventojų sveikatos problemoms spręsti. Vis dèlto negalima sakyti, kad Lietuvoje iki šiol nebuvo nieko daroma stengiantis sumažinti kai kurių hospitalizacijų skaičių. Siekiant spręsti šią problemą jau imtasi tam tikrų veiksmų, nes:

- nuo $2012 \mathrm{~m}$. sausio $1 \mathrm{~d}$. buvo įteisintas mokejjimas šeimos gydytojams už gerus darbo (sergančiųjų lètinèmis ligomis sveikatos priežiūros) rezultatus pagal sergančiųjų arterine hipertenzija hospitalizacijos rodiklį1;

- nuo $2011 \mathrm{~m}$. liepos $1 \mathrm{~d}$. buvo įteisintas mokèjimas už gerus darbo rezultatus, vertinamus pagal sergančiųjų cukriniu diabetu hospitalizacijos ir sergančiųjų bronchine astma hospitalizacijos rodiklius ${ }^{52}$.

- Tačiau šių priemonių veiksmingumas kartais yra ginčytinas, nes tikètina, kad šeimos gydytojai nuo šiol neretai vengia siųsti pacientus hospitalizuoti net esant reikalui, dèl to paciento būklè dar labiau pasunkẻja. Tad žvelgiant $\mathfrak{i}$ ateities perspektyvas reiktų ịvertinti galimas kiekvienos priemonès grèsmes, nors siekiamas tikslas ir yra sveikintinas. Juolab kad Lietuvoje dar daug priemonių, galinčių sumažinti IH skaičių, yra vis dar neišnaudotos. Galimi kitokie politiniai, vadybiniai sprendimai turètų apimti šiuos aspektus:

- gydytojų darbo praktikos pokyčiai (išnaudoti visas ambulatorinio gydymo galimybes, lètinèmis ligomis sergančius pacientus stebèti ir gydyti pirminès sveikatos priežiūros ịstaigose ir tik negavus teigiamo rezultato siųsti stacionariai gydyti; patvirtinti ligų gydymo standartus ambulatorinėmis ir stacionaro sąlygomis; užtikrinti gydytojų ir / arba slaugytojų vizitus na-

51 LR sveikatos apsaugos ministro $2011 \mathrm{~m}$. spalio 4 d. ịsakymas Nr. V-882 „Dèl Lietuvos Respublikos sveikatos apsaugos ministro $2005 \mathrm{~m}$. gruodžio 5 d. ịsakymo Nr. V-943 „Dèl pirminès ambulatorinès asmens sveikatos priežiūros paslaugų organizavimo ir apmokejimo tvarkos aprašo bei pirminès ambulatorinès asmens sveikatos priežiūros paslaugų ir bazinių kainų sąrašo tvirtinimo“ pakeitimo“. Valstybès žinios. 2011, Nr. 122-5774.

52 LR sveikatos apsaugos ministro 2012 m. rugpjūčio 3 d. ịsakymas Nr. V-757 „Dèl Lietuvos Respublikos sveikatos apsaugos ministro $2005 \mathrm{~m}$. gruodžio 5 d. ịsakymo Nr. V-943 „Dèl Pirminès ambulatorinès asmens sveikatos priežiūros paslaugų organizavimo ir apmokèjimo tvarkos aprašo bei Pirminès ambulatorinès asmens sveikatos priežiūros paslaugų ir bazinių kainų sąrašo tvirtinimo" pakeitimo“. Valstybès žinios. 2012, Nr. 94-4863. 
mie; didinti šeimos gydytojų atsakomybę ir kokybę tiriant ir siunčiant stacionariai gydyti);

- sveikatos priežiūros infrastruktūros, išteklių pokyčiai (įteisinti kardiologijos dienos stacionaro paslaugas; plèsti telemedicinos paslaugas ir padaryti jas kuo labiau prieinamas);

- prevencinė veikla (plètoti skiepijimų gripo ir pneumokokine vakcina apimtis; užsiimti ligų prevencija, ankstyva diagnostika, mokymu);

- gydytojų darbo sąlygų pokyčiai (šeimos gydytojams sudaryti galimybes daugiau laiko skirti pacientams; kelti gydytojų kvalifikaciją; gerinti darbo sąlygas mažesnèse savivaldybèse $)^{53,54}$.

Ateityje gali būti naudinga atlikti papildomus tyrimus vertinant IH mūsų šalyje. Ypač tai svarbu kalbant apie problemines savivaldybes - ryški IH problema atskirose teritorijose gali padèti nustatyti lokalias arba sistemines priežastis, kurias pašalinus sumažètų IH skaičius visoje šalyje. Kartu būtų naudinga atlikti pakartotinių hospitalizacijų rodiklių analizę - tai padètų ịvertinti ambulatorinès ir stacionarinės sveikatos priežiūros teikèjų bendradarbiavimą, stacionarinès priežiūros kokybę.

\section{Išvados}

1. Lietuvoje, kaip ir kitose šalyse, kuriose sveikatos priežiūros paslaugos gyventojams yra daugiausiai finansuojamos iš biudžeto, yra aktuali IH problema, nes $2012 \mathrm{~m}$. šalyje 16,2 proc. aktyvaus gydymo hospitalizacijų laikomos išvengiamomis (110,8 tūkst.). Daugiausiai IH buvo dèl cukrinio diabeto ir jo komplikacijų, krūtinès anginos, stazinio širdies nepakankamumo, gripo ir pneumonijos. Gyventojų grupių IH skaičius, tenkantis 1000 gyv., skyrèsi. . Vaikai ir pensinio amžiaus gyventojai, vyrai ir kaimo gyventojai buvo dažniau hospitalizuojami dèl AVL nei darbingo amžiaus asmenys, moterys ir miesto gyventojai. I̦ šiuos veiksnius reikia atsižvelgti nustatant rizikos grupes, tačiau jie negali būti tiesiogiai veikiami siekiant sumažinti IH skaičių.

2. Dažniausiai pacientai ị ligoninę atsiguldavo atvykę su siuntimu, ypač dèl lètinių ligų, kurias galima valdyti ambulatoriniame lygyje. Tokia tendencija rodo neefektyvų ambulatorinès sveikatos priežiūros darbą kontroliuojant lètines ligas ir vengiant jų komplikacijų.

3. Savivaldybiu IH rodikliai $2012 \mathrm{~m}$. svyravo nuo 27 atv. iki 57,7 atv., tenkančių 1000 gyv., o vyrų ir moterų IH rodikliai savivaldybèse stipriai kore-

53 LR sveikatos apsaugos ministerijos 2014 m. spalio 9 d. raštas Nr. (1.1.20-30)10-8883 „Dèl pateiktų pastabų vertinimo".

54 Freund, T., et al., supra note 31. 
liavo, todèl ambulatorinès sveikatos priežiūros problemos yra sisteminès, lokalizuotos savivaldybèse.

4. Siekiant mažinti IH skaičių šalyje reikia išnagrinèti daugiau nei vienerių metų duomenis. Tikslinga atlikti atskirus tyrimus probleminėse savivaldybėse, siekiant nustatyti pagrindines sistemines ir lokalias IH priežastis. Kartu būtų naudinga atsižvelgti ị pakartotinių hospitalizacijų skaičių, šeimos gydytojų, antrinio lygio gydytojų pagal profilius skaičių bei ligoninės lovų skaičių savivaldybėse, teikiamų ambulatorinių paslaugų spektrą, sveikatos būklès rodiklius.

5. Rekomenduojama pasinaudoti užsienio šalių patirtimi ir tarptautine gerąja praktika mažinant $\mathrm{IH}$ skaičiu politiniais ir vadybiniais sprendimais: gerinti gydytojų darbo praktiką, tobulinti sveikatos priežiūros infrastruktūrą ir didinti ambulatorinès sveikatos priežiūros išteklius, užsiimti prevencine veikla, gerinti gydytojų darbo sąlygas (ypač mažesnèse savivaldybèse).

\section{Literatūra}

1. Agency for Healthcare Research and Quality. Prevention Quality Indicators Overview. U.S. Department of Health and Human Services [interaktyvus]. 2015 [žiūrèta 201502-10]. <http://www.qualityindicators.ahrq.gov/modules/pqi_overview.aspx>.

2. Australian Institute of Health and Welfare. National Healthcare Agreement: PI 22-Selected potentially preventable hospitalisations, 2012 [interaktyvus]. Metadata Online Registry, 2015 [žiūrèta 2015-02-10]. <http://meteor.aihw.gov.au/content/ index.phtml/itemId/443687>.

3. Australian Institute of Health and Welfare. Primary and Community Health [interaktyvus]. Metadata Online Registry, 2015 [žiūrèta 2015-02-10]. <http://meteor. aihw.gov.au/content/index.phtml/itemId/393484>.

4. Basu, A.; Brinson, D. The effectiveness of interventions for reducing ambulatory care sensitive hospitalisations: a systematic review. HSAC Report. 2008, 1(6).

5. Billings, J.; Anderson, G. M.; Newman, L. S. Recent Findings on Preventable Hospitalizations. Health Affairs. 1996, 15(3): 239-249.

6. Bindman, A. B., et al. Preventable Hospitalizations and Access to Health Care. The Journal of the American Medical Association. 1995, 274(4): 305-311.

7. Fill, J.M.; Mainous, A. G. The role of provider continuity in preventing hospitalizations. Archives of Family Medicine. 1998, 7(4): 352-357.

8. Freund, T., et al. Strategies for Reducing Potentially Avoidable Hospitalizations for Ambulatory Care-Sensitive Conditions. Annals of Family Medicine. 2013, 11(4): 363370 .

9. Guo, L., et al. How are age and payors related to avoidable hospitalization conditions? Managed care quarterly. 2001, 9(4): 33-42. 
10. Health Outcomes Section, Development and Resources Branch, Public Health Division. The Victorian Ambulatory Care Sensitive Conditions Study: Preliminary Analyses [interaktyvus]. Public Health Division, Victorian Government Department of Human Services, Melbourne, Victoria, 2001 [žiūrèta 2015-02-10]. <http://docs. health.vic.gov.au/docs/doc/D98EB1945C0A612ECA25787300137A6F/\$FILE/ prelimanalyses.pdf $>$.

11. Institute for Healthcare Improvement. Readmissions. Reduce Avoidable Readmissions [interaktyvus]. Cambridge, 2015 [žiūrèta 2015-02-11]. <http://www.ihi.org/topics/ readmissions/Pages/default.aspx $>$.

12. Jackson, G.; Tobias, M. Potentially avoidable hospitalisations in New Zealand, 198998. Australian and New Zealand Journal of Public Health. 2001, 25(3): 212-221.

13. Jiang, H. J.; Russo, C. A.; Barrett, M. L. HCUP Statistical Brief \#72. Nationwide Frequency and Costs of Potentially Preventable Hospitalizations, 2006 [interaktyvus]. U.S. Agency for Healthcare Research and Quality, Rockville, 2009 [žiūrèta 2015-0210]. <http://www.hcup-us.ahrq.gov/reports/statbriefs/sb72.jsp>.

14. Katterl, R., et al. Potentially avoidable hospitalisations in Australia: Causes for hospitalisations and primary care interventions. PHCRIS Policy Issue Review. Adelaide: Primary Health Care Research \& Information Service, 2012.

15. Kowalski, A. F. Reducing asthma morbidity and mortality. Cost containment strategies. American Association of Occupational Health Nurses. 2000, 48(9): 418422.

16. LR sveikatos apsaugos ministerija. Savivaldybių gydytojai siunčia signalus apie dramatišką specialistu poreikị rajonuose [interaktyvus]. Vilnius, 2013 [žiūrèta 201502-11]. <http://www.sam.lt/go.php/lit/Savivaldybiu-gydytojai-siuncia-signalus-apiedramatiska-specialistu-poreiki-rajonuose $>$.

17. LR sveikatos apsaugos ministerija. Vyriausieji SAM respublikos specialistai pritare integruotos sveikatos priežiūros igyvendinimo planui [interaktyvus]. Vilnius, 2013 [žiūrèta 2015-02-11]. <http://www.sam.lt/go.php/lit/Vyriausieji-SAM-respublikosspecialistai-pritare-integruotos-sveikatos-prieziuros-igyvendinimo-planui>.

18. LR sveikatos apsaugos ministerijos 2014 m. spalio 9 d. raštas Nr. (1.1.20-30)10-8883 „Dèl pateiktų pastabų vertinimo“.

19. LR sveikatos apsaugos ministro $2011 \mathrm{~m}$. spalio 4 d. įsakymas Nr. V-882 „Dèl Lietuvos Respublikos sveikatos apsaugos ministro $2005 \mathrm{~m}$. gruodžio 5 d. įsakymo Nr. V-943 „Dèl pirminès ambulatorinès asmens sveikatos priežiūros paslaugų organizavimo ir apmokejjimo tvarkos aprašo bei pirminès ambulatorinès asmens sveikatos priežiūros paslaugų ir bazinių kainų sąrašo tvirtinimo“ pakeitimo“. Valstybès žinios. 2011, Nr. 122-5774.

20. LR sveikatos apsaugos ministro $2012 \mathrm{~m}$. rugpjūčio $3 \mathrm{~d}$. įsakymas Nr. V-757 „Dèl Lietuvos Respublikos sveikatos apsaugos ministro 2005 m. gruodžio 5 d. ìsakymo Nr. V-943 „Dèl Pirminès ambulatorinès asmens sveikatos priežiūros paslaugų organizavimo ir apmokejjimo tvarkos aprašo bei Pirminès ambulatorinès asmens sveikatos priežiūros paslaugų ir bazinių kainų sąrašo tvirtinimo" pakeitimo“. Valstybès žinios. 2012, Nr. 94-4863. 
21. LR sveikatos apsaugos ministro $2011 \mathrm{~m}$. gegužès 26 d. ịsakymas Nr. V-532 „Dèl Lietuvos Respublikos sveikatos apsaugos ministro 1998 m. lapkričio 26 d. ìsakymo Nr. 687 „Dèl medicininès apskaitos dokumentų formų tvirtinimo“ pakeitimo“. Valstybès žinios. 2011, Nr. 65-3053.

22. Magan, P., et al. Geographic variations in avoidable hospitalizations in the elderly, in a health system with universal coverage. BMC Health Services Research. 2008, 8(42): 48-52.

23. Maslow, K.; Ouslander, J. G. Measurement of Potentially Preventable Hospitalizations [interaktyvus]. Long-term Quality Alliance, 2012 [žiūrèta 2015-02-10]. <http://www. ltqa.org/wp-content/themes/ltqaMain/custom/images//PreventableHospitalizatio ns_021512_2.pdf >.

24. Mekšriūnaitè S.; Gurevičius R. Išvengiamų hospitalizacijų mastas Lietuvoje 2012 metais: bendra apžvalga. Visuomenés sveikata. 2014, 4(67): 26-35.

25. Muenchberger, H.; Kendall, E. Predictors of preventable hospitalization in chronic disease: Priorities for change. Journal of Public Health Policy. 2010, 32(2): 150-163.

26. Nutffield Trust \& the Health Foundation. Indicator: Potentially preventable emergency hospital admissions. QualityWatch [interaktyvus]. 2015 [žiūrèta 2015-02-10]. <http:// www.qualitywatch.org.uk/indicator/potentially-preventable-emergency-hospitaladmissions $>$.

27. Page, A., et al. Atlas of Avoidable Hospitalisations in Australia: ambulatory caresensitive conditions. Adelaide: PHIDU, University of Adelaide, 2007.

28. Parchman, M. L.; Culler, S. Primary care physicians and avoidable hospitalizations. The Journal of Family Practice. 1994, 39(2): 123-128.

29. Rizza, P., et al. Preventable hospitalization and access to primary health care in an area of Southern Italy. BMC Health Services Research. 2007, 7: 134-142.

30. Rosano, A., et al. Hospitalization for ambulatory care sensitive conditions and the role of primary care in Italian regions. Italian Journal of Public Health. 2011, 8(1): 77-88.

31. Segal, M., et al. Medicare-Medicaid Eligible Beneficiaries and Potentially Avoidable Hospitalizations. Medicare \& Medicaid Research Review. 2014, 4(1).

32. Statistics Canada. Health system performance, effectiveness [interaktyvus]. Ottawa, 2015 [žiūrèta 2015-02-10]. <http://www.statcan.gc.ca/pub/82-221-x/2013001/def/ def3-eng.htm\#effec3ac >.

33. V. P. Andriukaitis: „Virškvotinių paslaugu sveikatos priežiūros sistemoje turi nelikti“ [interaktyvus]. Vaistai.lt, 2013 [žiūrèta 2015-02-12]. <http://www.vaistai. lt/V-P-Andriukaitis-Virskvotiniu-paslaugu-sveikatos-prieziuros-sistemoje-turinelikti-2147.html>.

34. Valstybinė ligonių kasa. Ligonių kasos: 2013-ųų apžvalga. Vilnius, 2014. 


\title{
Avoidable Hospitalizations as an Indicator of Ambulatory Healthcare in Lithuania in 2012: What Can Be Done?
}

\author{
Sandra Mekšriūnaitè \\ Institute of Hygiene, Health Information Centre, Lithuania \\ Romualdas Gurevičius \\ Institute of Hygiene, Health Information Centre, Lithuania
}

Background. Avoidable hospitalizations (AH) are hospitalizations that could be avoided through accessible and effective ambulatory care setting which provides preventive care, early diagnostics and disease management. The scale of AH in Lithuania up to this date has been scarcely researched, but it is a topical issue as it is in all other countries with health systems that provide universal coverage. Purposeful strategies in policy and management that increases the effectiveness of ambulatory care setting could reduce the number of $A H$ and save budget as stationary care is known to be very expensive. The aim of this study is to evaluate patterns of AH in Lithuania in 2012 and to recommend strategies for reducing the number of $A H$.

Materials and methods. The research was based on Australian methodology, which is used to monitor the quality of ambulatory care. The study population was all residents of Lithuania that were hospitalized due to ambulatory care sensitive conditions (ACSC) in 2012. ACSC were selected by ICD-10-AM code and ACHI procedure codes. Data on hospitalizations was gathered from National Health Insurance Fund Information System ("Sveidra") and Statistics of Lithuania.

Results. Over 110 thousands of acute care hospitalizations in Lithuania in 2012 can be considered as avoidable. It accounted for 16,2 percent of overall acute care hospitalizations. The majority of $A H$ were due to diabetes and its complications, angina, congestive heart failure, influenza and pneumonia. AH rates differed by gender, age and residence place (urban/rural). The majority of patients were at pre-school and retirement age. AH rate for males and rural residents was higher than for females and urban residents. The majority of patients were hospitalized with committal. Rates of AH in municipalities ranged from 27.0 to 57.7 cases per 1000 population. Differences among municipalities can be considered as consequences of systematic causes in municipalities.

Conclusions. AH is a significant problem in Lithuania. Reducing the number of AH provides an opportunity to reduce the expenditure of National Health Insurance Fund. Not all opportunities are being used in ambulatory care to avoid the hospitalization. Further research on $A H$ is recommended to elucidate essential reasons and to plan the strategies to increase the effectiveness of ambulatory care setting.

Keywords: ambulatory care sensitive conditions, avoidable hospitalizations, potentially preventable hospitalizations, diabetes mellitus, in-patient care, out-patient care.

Sandra Mekšriūnaitė, Higienos instituto Sveikatos informacijos centro Biostatistinès analizės skyriaus vyr. specialistė. Mokslinių tyrimų kryptys: išvengiamas mirtingumas, išvengiamos hospitalizacijos. 
Sandra Mekšriūnaitė, Institute of Hygiene, Health Information Centre, Division of Biostatistical Analysis, Chief specialist. Research fields: avoidable mortality, avoidable hospitalizations.

Romualdas Gurevičius, biomedicinos mokslų daktaras, Higienos instituto Sveikatos informacijos centro vadovas. Mokslinių tyrimų kryptys: epidemiologija, biostatistika, sveikatos priežiūros vadyba, sveikatos technologijų vertinimas.

Romualdas Gurevičius, Doctor of Biomedical Sciences, Institute of Hygiene, Head of Health Information Centre. Research fields: epidemiology, biostatistics, healtcare management, health technology assessment. 